\title{
PENGEMBANGAN MEDIA PEMBELAJARAN INTERAKTIF BERBASIS LMS MOODLE DITINJAU DARI COGNITIVE LOADS THEORY
}

\author{
Alfret Ade Putra ${ }^{1}$, Nuryadi ${ }^{2}$ \\ Fakultas Keguruan dan Ilmu Pendidikan, Universitas Mercu Buana Yoyakarta. \\ e-mail: alfredadeputra1@.gmail.com ${ }^{1}$, nuryadi@mercubuana-yogya.ac.id ${ }^{2}$
}

\begin{abstract}
The development of E-Learning is based on the development of IPTEK as a resource for the fulfillment of core competencies in curriculum 2013 which facilitate students and teachers in the learning process. The research uses $R \& D$ design, based from cognitive loads theory with the Borg $\&$ Gall development model. The steps are: research and information collection, research planning, initial product development, preliminary field test involving 4 students, revision of preliminary field test result, wider field test involving 8 students, test revision A field, a feasibility test involving 32 students, and a revision of the feasibility of a trial subject in research is a grade VIII student of SMP Negeri 1 Mlati, Kab. Sleman, D.I. Yogyakarta. Data is collected through polls and observations during trials, and then research results are analyzed with quantitative descriptive analysis techniques. Media expert responses get an average score of 3.91. While the responses of the material experts acquired an average score of 3.60 showed a Moodle-based e-learning is decent in terms of media and worthy of material terms. The results of the study on field implementation test show that all students of class VIII C percentage of class submission are above $86 \%$. The results of the students ' responses to small and large scale trials showed that the majority of students gave positive feedback on learning activities using LMS Moodle-based e-learning media. LMS Moodle's final e-learning product contains material, video links, ppt links, quizzes, articles around mathematical numeral patterns, chat and discussion forums. Thus, from the test results of the implementation of the field can be concluded that E-learning based on LMS Moodle Mathematics learning for students of grade VIII C SMP Negeri 1 Mlati, with material "number pattern" is feasible as one of the sources Study both individually and in groups.
\end{abstract}

Keywords: Development of E-learning, LMS Moodle, Cognitive Loads Theory Mathematics, Numbers Pattern.

\section{PENDAHULUAN}

Kesadaran akan pentingnya sebuah pendidikan Negara Kesatuan Republik Indonesia (NKRI) di dalam pembukaan Undang-Undang Dasar (UUD) 1945 menyatakan bahwa salah satu tujuan kemerdekaannya ialah mencerdaskan kehidupan bangsa. oleh karena itu setiap warga Indonesia tanpa, memandang status sosial, ras, etnis, agama dan gender berhak memperoleh pendidikan yang layak serta bermutu sesuai dengan minat dan bakat yang dimilikinya. Hadirnya pendidikan yang bermutu di prakarsai oleh adanya sumber daya manusia yang berkualitas, yaitu warga negara yang unggul secara intelektual, kompeten, bermoral, inovatif serta produktif dalam karya, bermartabat dengan mengaplikasikan akhlak mulia dalam kehidupan sehari-hari, tanggung jawab dalam menggunakan Ilmu Pengetahuan dan Teknologi (IPTEK) serta berdaya saing terhadap bangsa lain dan ikut serta di dalam pembangunan kemajuan bangsa.

Pendidikan merupakan hal yang sangat penting dalam mencerdaskasn kehidupan bangsa dan wahana yang strategis di dalam pengembangan eksistensi sumber daya manusia. Melalui pendidikan diharapkan manusia dapat tumbuh dan berkembang untuk menjadi pribadi yang lebih baik. Menurut Trianto (Nuryadi, 2014: 1), pendidikan adalah salah satu bentuk perwujudan kebudayaan manusia yang dinamis dan sarat akan 
perkembangan. Oleh karena itu, perubahan atau perkembangan di dalam dunia pendidikan adalah hal yang seharusnya terjadi sejalan dengan perubahan atau perkembangan zaman. Perubahan dalam arti perbaikan pendidikan perlu terus-menerus dilakukan sebagai antisipasi kepentingan masa depan. Pendidikan yang mampu mendukung pembangunan di masa mendatang adalah pendidikan yang mampu mengembangkan potensi siswa serta menjadikannya sebagai tajuk utama pembangunan bangsa.

Menurut Hamalik, (2014: 2) fungsi pendidikan adalah untuk menyiapkan peserta didik. kata "menyiapkan" diartikan bahwa peserta didik pada hakikatnya belum siap, tetapi perlu disiapkan dan sedang menyiapkan dirinya sendiri. Hal ini merujuk pada proses yang berlangsung sebelum peserta didik itu siap untuk terjun ke ranah kehidupan yang nyata. Dalam kurikulum 2013 disebutkan bahwa salah satu cara untuk menghadapi tantangan perkembangan IPTEK diperlukan sumber daya manusia yang memiliki kemampuan hidup sebagai pribadi dan warga negara yang beriman, produktif, kreatif, inovatif dan afektif. Untuk itu, program pendidikan yang dikembangkan perlu menekankan kemampuan berpikir pada siswa. Pengembangan kemampuan berpikir ini dapat dilakukan melalui pembelajaran matematika. Belajar selalu membutuhkan kemampuan kognitif untuk memproses informasi yang diperoleh dari lingkungan, dan berpikir merupakan bagian dari kemampuan kognitif siswa dalam menghadapi setiap kegiatan belajar sehingga siswa harus diajak untuk berpikir, Subanji (Yohanes, dkk 2016: 187). Beban kognitif didefinisikan sebagai beban dalam melakukan tugas tertentu yang berdampak pada sistem pengolahan kognitif.

Beban kognitif dalam memori kerja disebabkan oleh tiga sumber, yaitu: intrinsic cognitive load (kemampuan menerima dan mengolah informasi), extraneous cognitive load (usaha mental), dan germane cognitive load (kemampuan penalaran) Sweller (2010: 123-138). Intrinsic cognitive load merupakan beban kognitif dalam memposes informasi yang diterima, terbentuk akibat kompleksitas materi daninterkoneksi yang tinggi dalam memproses materi pembelajaran yang masuk kedalam memori kerja. ICL sangat terkait dengan intrinsic processing pada memori kerja ketika mengkonstruksi skema kognitif. Terkait dengan pembelajaran matematika di sekolah menengah pertama (SMP) kelas VIII khususnya materi pola bilangan terdapat kompetensi inti yang harus dikuasai oleh siswa diantaranya adalah kemampuan mengolah, menyaji dan menalar dalam ranah (mengurai, merangkai, memodifikasi, dan membuat) kata menalar berkaitan dengan kemampuan berpikir intuitif siswa dalam menganalisa masalah matematika. Untuk menjelaskan masalah dan metode penyelesaian matematika beberapa materi membutuhkan kemampuan intuitif. Kata 'Intuitif' sendiri merujuk pada pendapat, Dreyfus \& Eisenberg (1982: 360-380) mengatakan bahwa pemahaman secara intuitif sangat diperlukan sebagai "jembatan berpikir" manakala seseorang berupaya untuk menyelesaikan masalah kontektual dan memandu menyelaraskan kondisi awal dengan tujuan. Dengan kata lain, untuk beberapa siswa pada saat menyelesaikan masalah matematika. siswa telah mengetahui atau menemukan solusi/jawaban dari suatu masalah sebelum siswa menuliskan langkah penyelesaiannya. Meskipun, pada saat mereka menemukan ide awal dalam penyelesaian masalah atau langkah apa yang paling cocok untuk menyelesaikan masalah tersebut. Munculnya ide yang datang secara seketika dan bersifat otomatis (immediate) atau muncul tiba-tiba (suddenly) merupakan cara berpikir yang melibatkan intuisi.

Menurut Fischbein (Nuryadi, 2019), intuisi adalah proses kognitif yang spontan dan segera, berdasarkan pada skema tertentu. Ada dua jenis intuisi yang dikategorikan oleh Fischbein yaitu intuisi untuk memahami masalah yang disebut afirmatory dan intuisi untuk menyelesaikan masalah yang disebut antisipatory. Kedua jenis intuisi ini harus berjalan dalam pemecahan masalah sehingga memperoleh hasil yang maksimal. Dalam 
Pengembangan Media Pembelajaran Interaktif Berbasis Lms Moodle Ditinjau Dari Cognitive Loads Theory

Alfret Ade Putra ${ }^{1}$, Nuryadi ${ }^{2}$

pemecahan masalah matematika terkadang terdapat sesuatu tanpa pemikiran secara mendalam yang digunakan untuk menyelesaikannya, walaupun sesuatu tersebut belum tentu dapat dibuktikan kebenarannya. Sebagai contoh, untuk membuktikan kebenaran rumus $n x n$ suku ke-n dari sebuah pola persegi $S n=n^{2}$ maka siswa awalnya akan berpikir secara sepintas (spontan) cara pembuktian yang digunakan berdasarkan pola yang ada, apakah bukti langsung atau tidak langsung. Ini merupakan bagian dari ciri berpikir intuitif.

Untuk memenuhi kompetensi inti serta kompetensi dasar matematika kelas VIII pada materi pola bilangan maka dibutuhkan media belajar bagi siswa itu sendiri, baik itu buku pelajaran maupun gabungan beberapa media yang dapat dikolaborasikan menjadi sebuah multimedia guna mendukung proses pembelajaran. Media disini berfungsi sebagai alat transfer yang dapat memvisualisasikan pembelajaran yang diterima oleh siswa. Menurut Istiyanto (2011), multimedia adalah media yang menggabungkan dua unsur atau lebih yang terdiri dari teks, grafik, gambar, foto, audio, dan animasi secara terintegrasi. Menurut Mayer (2009: 3), multimedia didefinisikan sebagai presentasi materi dengan menggunakan kata-kata (verbal form) sekaligus gambar-gambar (pictorial form). Salah satu implementasi penggunaan teknologi multimedia pembelajaran adalah menggunakan media e-learning yang mana didalamnya media yang disajikan kedalam materi dapat berupa audio, video, teks, grafik, foto serta animasi. Menurut Prakoso (2005), e-learning merupakan aplikasi internet yang dapat menghubungkan antara pendidik dengan peserta didik dalam sebuah ruang belajar online. dengan menggunakan e-learning maka pendidik dan murid tidak harus berada dalam satu ruang dan waktu yang sama. Proses pendidikan dapat berjalan kapan saja dengan mengabaikan dua hal tersebut.

Moodle merupakan akronim dari Modular Object-Oriented Dynamic Learning Environment. Menurut Prakoso (2005) moodle adalah sebuah paket perangkat lunak yang berguna untuk membuat dan mengadakan kursus/pelatihan/pendidikan berbasis internet. Moodle menurut Darmawan (2014: 69) merupakan CMS (Course Management System) atau LMS (Learning Management System) berbasis open source (di bawah lisensi GNU Public License) diberikan secara gratis sebagai perangkat lunak, sehingga Moodle adalah perangkat lunak berbentuk CMS/LMS yang bersifat open source yang dapat di-copy, didownload, dan dimodifikasi untuk membuat sebuah kursus/pembelajaran yang berbasis internet. Dari hasil observasi dengan guru matematika di SMP Negeri 1 Mlati selama pada tanggal 18 Juli 2019 diketahui bahwa dalam proses pembelajaran guru tidak pernah menggunakan media pembelajaran seperti media belajar interaktif berupa e-learning. Fasilitas yang terdapat di sekolah tersebut mendukung koneksi wifi, LCD dan laboratorium komputer namun belum dimaksimalkan dalam proses pembelajaran. Berdasarkan uraian di atas, maka penulis tertarik untuk melakukan penelitian berjudul "Pengembangan Media Pembelajaran Interaktif Berbasis LMS Moodle Untuk SMP Kelas VIII Ditinjau Dari Cognitive Loads Theory"

\section{JENIS PENELITIAN}

Penelitian ini merupakan penelitian pengembangan (Research and Developmennt). Menurut sukmadinata (2012: 164), penelitian dan pengembangan adalah suatu prosesproses atau langkah-langkah untuk mengembangkan suatu produk baru atau menyempurnakan produk yang telah ada, yang dapat dipertanggungjawabkan. Produk yang dikembangkan dalam penelitian ini berupa materi pelajaran, strategi dan media pembelajaran untuk diimplementasikan pada rombongan belajar tingkat VIII SMP. Sedangkan produk hasil pengembangan ialah berupa media pembelajaran interaktif berbasis e-learning dengan program situs web Modular Object Oriented Dynamic 
Learning Environment (Moodle) yang disusun berdasarkan langkah-langkah sistematis dan akan diuji kelayakannya baik segi materi dan media.

Desain penelitian yang digunakan dalam penelitian ini adalah pengembangan yang di adaptasi dari langkah-langah pengembangan media yakni Borg and Gall (1983: 775) bertujuan untuk menghasilkan e-learning berbasis LMS moodle yang dapat dimanfaatkan dalam proses pembelajaran. Model penelitian dan pengembangan menurut Borg and Gall ini meliputi sepuluh langkah, yaitu: (1) Penelitian dan pengumpulan informasi; (2) Perencanaan penelitian; (3) Pengembangan produk awal; (4) Uji lapangan terbatas; (5) Revisi hasil uji lapangan terbatas; (6) Uji lapangan lebih luas; (7) Revisi hasil uji lapangan; (8) Uji kelayakan; (9) Revisi hasil kelayakan; (10) Desiminasi dan sosialisasi produk akhir. Langkah-langkah metode penelitian seperti pada gambar 1 dibawah ini:

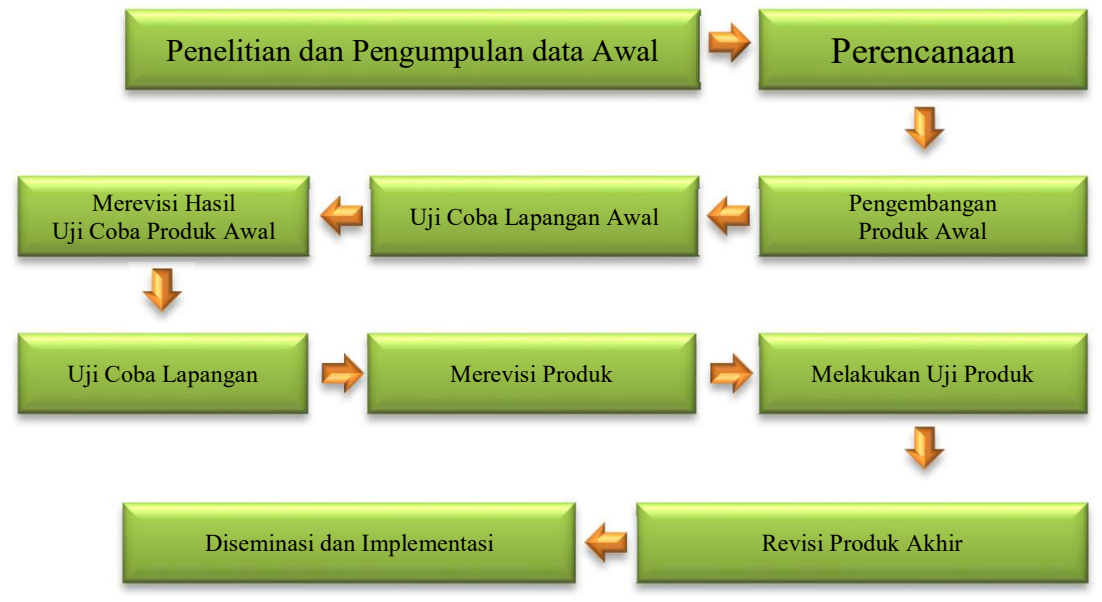

Gambar 1. Bagan Langkah-langkah Penelitian Pengembangan

\section{PEMBAHASAN}

Serangkaian penelitian ini dirancang untuk menghasilkan produk e-learning berbasis LMS moodle pembelajaran matematika bagi siswa kelas VIII SMP serta mengetahui kualitas E-learning melalui validasi ahli dan uji coba kelayakan. Dalam pembahasan ini dijelaskan dialog antara beberapa hasil dari tahapan penelitian pengembangan berdasarkan metode Borg \& Gall (1989) dengan kajian teori yaitu meliputi validasi media, validasi materi, uji coba lapangan awal dan uji pelaksanaan lapangan.

\section{a. Validasi Ahli Media}

Hasil validasi media menunjukkan bahwa kualitas E-learning pada media terdiri dari 4 aspek yakni aspek bahasa, aspek efek bagi strategi pembelajaran, aspek rekayasa media e-learning dan aspek tampilan visual. Secara keseluruhan berdasarkan 21 butir penilaian untuk ahli media pembelajaran yaitu Bapak M. Ihsaan Fathoni, M.Pd. mempunyai rata-rata 3,91 dengan kriteria baik.

Dalam segi galat/kesalahan tampilan mendapatkan beberapa saran dari ahli untuk halaman depan perlu dirapikan lagi, untuk materi yang berupa link hendaknya langsung akses download. Sedangkan dari segi gambar dan warna perlu dibuat lebih menarik. Hasilnya telah sesuai dengan pendapat Pujirianto (2005: 47) yang menyatakan bahwa warna memiliki fungsi dan arti yang berpengaruh pada psikologi seseorang yang melihatnya. Dengan menggunakan tampilan yang menarik serta kemudahan dalam menggunakan media, siswa sebagai pengguna akan menekan aktivitas Extraneous Cognitive Loads yang berlebihan akibat aktivitas otak dalam 
Pengembangan Media Pembelajaran Interaktif Berbasis Lms Moodle Ditinjau Dari Cognitive Loads Theory

Alfret Ade Putra ${ }^{1}$, Nuryadi ${ }^{2}$

memproses visualitas dan menggunakan LMS Moodle sehingga tujuan pembelajaran mandiri akan tercapai.

\section{b. Validasi Materi}

Hasil validasi materi menunjukkan bahwa kualitas E-learning pada materi terdiri dari 5 aspek yaitu aspek relevansi materi, aspek pengorganisasian materi, aspek evaluasi/latihan soal, aspek bahasa, aspek efek bagi strategi pembelajaran. Secara keseluruhan berdasarkan 25 butir penilaian untuk ahli materi pembelajaran yaitu Bapak Nanang Khuzaini, M.Pd. mempunyai rata-rata skor 3,6 dengan kriteria baik pada validasi angket dan diberi kesimpulan untuk layak diuji cobakan.

\section{c. Uji Coba Lapangan Awal}

Pada tahap uji coba lapangan awal apresiasi siswa terhadap E-learning berbasis LMS moodle pembelajaran matematika sangatlah baik. Uji coba lapangan awal dilakukan untuk subjek penelitian 4 orang siswa kelas VIII SMP Negeri 1 Mlati. Dalam pelaksanaannya sebagian besar siswa sudah bisa mengoperasikan media e-learning baik dengan menggunakan smartphone, tablet $p c$ atau komputer masih bertanya-tanya mengenai penggunaan namun secara keseluruhan kendala tersebut dapat ditangani. Secara keseluruhan mereka menyukai media belajar interaktif mandiri menggunakan e-learning LMS Moodle dan merasa terbantu dalam belajar. Penilaian siswa secara keseluruhan dari 3 aspek yang dinilai dan 8 butir memperoleh skor 4,5 dengan kriteria sangat baik. Setelah pelaksanaan uji coba lapangan awal, siswa merasa puas dengan media yang baru saja mereka gunakan.

\section{d. Uji Coba Lapangan}

Uji coba lapangan dilakukan untuk subjek penelitian siswa kelas VIII C SMP Negeri 1 Mlati dengan melibatkan 8 orang siswa. Penilaian siswa secara keseluruhan dari 3 aspek yang dinilai memperoleh skor 4,7 dengan kriteria sangat baik. Setelah pelaksanaan uji coba lapangan, siswa memberikan masukan tentang perbaikan pada media e-learning. Saran atau masukan dari siswa sebagai subjek uji coba lapangan untuk menambahkan kuis di setiap materi yang telah selesai dipelajari karena sebelumnya siswa harus menyelesaikan semua daftar course untuk mengikuti kuis.

\section{e. Uji Pelaksanaan Lapangan}

Uji pelaksanaan lapangan merupakan inti dari evaluasi E-learning berbasis LMS moodle pembelajaran matematika bagi siswa SMP kelas VIII C dengan jumlah responden yang lebih luas dan mencangkup seluruh siswa yang berjumlah 32 orang dalam kelas VIII C di SMP Negeri 1 Mlati, Kab. Sleman, D.I. Yogyakarta. Penilaian siswa secara keseluruhan dari 8 aspek yang dinilai memperoleh skor 4,43 dengan kriteria sangat baik. Penilaian tersebut tidak jauh berbeda dengan penilaian uji coba lapangan awal dengan selisih 0,07 yang mempunyai rata-rata skor 4,50 sehingga data dinyatakan valid. Pada tahap uji pelaksanaan lapangan ini tidak terdapat saran dari siswa untuk memperbaiki $E$ learning namun beberapa tanggapan siswa jika E-learning mempermudah belajar siswa.

Dari hasi uji produk E-learning yang telah dilaksanakan di kelas kelas VIII C SMP Negeri 1 Mlati menunjukkan hasil penilaian masing-masing kelas terhadap 
produk E-learning berbasis moodle pembelajaran matematika bagi kelas V termasuk kategori "sangat baik" dan secara keseluruhan produk pengembangan $E$ learning ini dapat dinyatakan "LAYAK".

\section{KESIMPULAN DAN SARAN}

Pengembangan media pembelajaran interaktif berbasis LMS moodle pembelajaran matematika materi pola bilangan bagi siswa kelas VIII SMP Negeri 1 Mlati telah menempuh 9 langkah pengembangan berdasarkan model pengembangan Borg \& Gall (1989) dan dinyatakan "LAYAK". Hal tersebut dibuktikan dengan beberapa hasil penelitian yaitu hasil Validasi Ahli Media, Validasi Ahli Materi, Uji Coba Lapangan Awal, Uji Coba Lapangan, dan Uji Pelaksanaan Lapangan. Validasi oleh ahli media yaitu Bapak M. Ihsaan Fathoni, M.Pd. memperoleh rata-rata skor 86 dengan rata-rata 4,09 dikategorikan "sangat baik" dan validasi oleh ahli materi yaitu Bapak Nanang Khuzaini, M.Pd. memperoleh skor 90 dengan rata-rata 3,6 dikategorikan "baik". Uji lapangan awal secara terbatas dengan subjek penelitian 4 orang siswa memperoleh skor 36 dengan ratarata 4,5 dikategorikan "sangat baik". Uji lapangan secara terbatas dengan subjek penelitian 8 orang siswa memperoleh skor 37,98 dengan rata-rata 4,7 dikategorikan "sangat baik". Uji pelaksanaan lapangan dengan subjek penelitian 32 orang siswa memperoleh skor 36,66 dengan rata-rata skor 4,6 dikategorikan "sangat baik"

Hasil pengembangan media pembelajaran interaktif berbasis LMS Moodle yang ditinjau dari cognitive loads theory dinyatakan efektif berdasarkan hasil tes instrumen siswa dan tes analisis pengembangan struktural serta terpadu pada produk e-learning yang dikembangkan. Dari hasil tes tersebut siswa secara konsisten menyatakan bahwa media pembelajaran interaktif berbasis LMS Moodle sangat efektif ditinjau dari Cognitive Load Theory.

Berdasarkan hasil penelitian yang diperoleh, maka dapat diberikan saran-saran yang diharapkan dapat bermanfaat sebagai berikut:

Bagi sekolah atau Bapak/Ibu Guru disarankan untuk dapat memanfaatkan e-learning dengan baik agar siswa dapat mengikuti perkembangan teknologi yang dimanfaatkan untuk kegiatan pembelajaran.

Bagi peneliti berikutnya yang akan mengembangkan e-learning disarankan untuk mengikuti perkembangan teknologi sesuai yang sekolah miliki seperti pengembangan $e$ learning berbasis LMS moodle dan Ispring Suite agar variasi penyampaian informasi lebih beragam.

\section{DAFTAR PUSTAKA}

Trianto. (200\&8. Model-model pembelajaran inovatif berorientasi konstruktivistik. Jakarta: Prestasi Pustaka.

Hamalik, O. (2005). Media Pendidikan. Bandung: PT. Citra Aditya Baktu.

Subanji, dkk. 2016. Beban Kognitif Siswa dalam Pembelajaran Materi Geometri. Jurnal Pendidikan. Vol. 1 (2): hal 187-195.

Sweller, J. (2010). Element Interactivity and Instrinsic, Extraneous, and Germane Cognitive Load. Educational Psychologu Review, 22(22), 1223-138.

Dreyfus, T. \& Eisenberg, T. (1982). Intuitive functional concepts: A baseline study on intuitions. Journal for Research in Mathematics Education, 13(5), 360 -380.

Fischbein, E. (1987). Intuition in science and mathematics an educational approach. Netherland: Reidel. 
Pengembangan Media Pembelajaran Interaktif Berbasis Lms Moodle Ditinjau Dari Cognitive Loads Theory

Alfret Ade Putra ${ }^{1}$, Nuryadi ${ }^{2}$

Istiyanto. 2011. Pengertian dan Manfaat Multimedia Pembelajaran, (Online), (http://istiyanto.com/pengertian-dan-manfaat-multimediapembelajaran). Diakses 11 Nopember 2011.

Mayer, R.E. 2009. Multimedia Learning: Prinsip-Prinsip dan Aplikasi. Terjemahan Teguh Wahyu Utomo.Yogyakarta: Pustaka Pelajar.

Nuryadi, N. (2014). Keefektifan Pendekatan CTL dan PPM Pembelajaran Matematika Metode GTG Ditinjau Keaktifan dan Prestasi Siswa. PYTHAGORAS: Jurnal Pendidikan Matematika, 9(1), 22-30.

Nuryadi, N. (2019). Pengembangan Media Matematika Mobile Learning Berbasis Android ditinjau dari Kemampuan Pemecahan Masalah. Jurnal pendidikan surya edukasi (JPSE), 5(1), 1-13.

Prakoso, K. S. 2005. Membangun E-learning dengan Moodle. Yogyakarta: ANDI.

Darmawan, D. 2014. Pengembangan E learning Teori dan Design. Bandung: PT. Remaja

Rosdakarya. 